International Research Journal of Management, IT \& Social Sciences
Available online at https://sloap.org/journals/index.php/irjmis/
Vol. 7 No. 6, November 2020, pages: 146-152
$\begin{aligned} & \text { ISSN: 2395-7492 } \\ & \text { https://doi.org/10.21744/irjmis.v7n6.1030 }\end{aligned}$

\title{
Comparison Effecting of Mixture on Three Meat Factors and Three Culinary Sectors on Consumers in Restaurant Nusa Dua
}

\author{
Gede Suarta ${ }^{a}$ \\ Ketut Sukada $^{\text {b }}$ \\ Wayan Suberata ${ }^{\mathrm{c}}$
}

\section{Article history:}

Submitted: 18 September 2020

Revised: 27 October 2020

Accepted: 09 November 2020

\section{Keywords:}

beef;

chicken;

hamburger;

kebab;

spaghetti;

\begin{abstract}
This study aims to find the best culinary mix of 3 meat factors, namely: chicken, pork, and beef mixed with 3 culinary factors, namely kebab, spaghetti, and hamburger. The research design used a factorial design with 3 replications, so that the total number of observations was 27 units including KA (chicken kebab), KB (pork kebab), KS (Cow Kebab), SA (Chicken Spaghetti, SB (Spaghetti Babi, SS (Spaghetti) Cow, HA (Chicken Hamberger), HB (Pig Hamberger, HS (Cow Hamberger) each repeated 3 times so that a $3 \times 3 \times 3$ factorial analysis occurs using analysis of variants processed with SPSS (Statistical Product System Solution), each variable is measured by the number of consumers who From the results of the Duncant Test, it was found that the culinary products that bought the most buyers were $37.56(\mathrm{P}<0.05)$, spaghetti $23.22(\mathrm{P}<0.05)$, hamberger $21.11(\mathrm{P}<0.5)$, while the desire to choose a mixture of meat was not significantly different, chicken was $31.67(\mathrm{P}>0.05$, beef 21.11 $(\mathrm{P}>0.05)$, pork was $23.11(\mathrm{P}>0,05)$ The interaction between culinary types and meat types was not significantly different $(\mathrm{P}>0.05)$ It can be concluded that the real type of kebab culinary is the most preferred by consumers.
\end{abstract}

International research journal of management, IT and social sciences (C) 2020. This is an open access article under the CC BY-NC-ND license (https://creativecommons.org/licenses/by-nc-nd/4.0/).

\section{Corresponding author:}

Gede Suarta,

Faculty of Animal Husbandry, Udayana University, Denpasar, Indonesia.

Email address: gedesuarta8@gmail.com

\footnotetext{
a Faculty of Animal Husbandry, Udayana University, Denpasar, Indonesia

${ }^{\mathrm{b}}$ Faculty of Animal Husbandry, Udayana University, Denpasar, Indonesia Faculty of Animal Husbandry, Udayana University, Denpasar, Indonesia 


\section{Introduction}

Visits by foreign tourists to the South Bali region have had a lot of changing effects, especially on the livelihoods of residents in the area. The development of a restaurant that previously served traditional culinary delights has now adapted a lot to the favorite culinary delights of the tourists themselves. In the past, not many residents were familiar with the terms hamburger, spaghetti, and kebab, with the entry of tourism into this area, now residents have become accustomed to enjoying these culinary delights (Sozer et al., 2007; Gallegos-Infante et al., 2010). These changes prompted restaurant developers to present this new product, both to international guests and to consumers who came from local areas. The development of these new culinary delights can be said to almost rival traditional local specialties, but these developments also enrich the variety of existing local culinary delights. Guests who are accustomed to using culinary like in their country, at this time there are still some who order back culinary delights that are used to being consumed in their country.

The increase in tourist visits has an impact on the development of local culinary in Bali Province. Not all international guests are familiar with traditional Balinese products such as Babi Guling (suckling piglet) and Ayam Betutu (chicken steam). According to the experience of old businessmen, some guests still want to order culinary products that are usually eaten in their area. On the other hand, many local consumers are getting used to enjoying products such as Kebab, Humberger, Spaghetti, and Rice Bowl. So based on this, to seek greater profit, restaurant entrepreneurs are also targeting consumers' desires to be fulfilled and shopping at their restaurant. Traditional products such as babi guling are only favored by guests from China, Taiwan, and Korean tourists, while tourists from America, Britain, Australia are still fond of culinary delights such as kebabs, hamburger, spaghetti. Seeing this phenomenon, restaurant and restaurant developers besides promoting traditional products, but also developing new culinary products according to tourists' enjoyment.

\section{Literature review}

Chicken, pork, and beef are the main ingredients for mixing culinary preparations, including kebab, spaghetti, and hamburger. Meat is a food source of animal protein favored by all levels of society because it tastes delicious and contains a high nutritional value (Short et al., 1996; Larsson \& Sjöquist, 1990; Widyantara et al., 2019). Meat is one of the livestock products that can hardly be separated from human life. Meat can cause satisfaction or pleasure for those who eat it because of its complete nutritional content so that the nutritional balance for life can be fulfilled. Agus et al. (2009), defines meat as all animal tissue and all products that are processed by the tissue are suitable for eating and do not cause health problems for those who eat it. Physical qualities of meat include $\mathrm{pH}$, water holding capacity, cooking losses, and texture. The physical quality of the meat is influenced by the process before and after cutting. Factors before slaughter that can affect meat quality are genetics, species, breed, type of livestock, sex, age, feed including additives (hormones, antibiotics, and minerals), and stress conditions. Post-slaughter factors that affect the quality of the meat include meat $\mathrm{pH}$, storage method, type of meat muscle, and location of the meat muscle (Kadafi et al., 2005).

The organoleptic properties of fresh meat are an important aspect. This is related to consumer considerations in choosing meat. Usually, consumers will find it easier to choose meat through physical appearance which includes color, texture, brightness, and flavor intensity of fresh meat. According to Agus et al. (2009), the appearance of meat is greatly influenced by factors during maintenance, handling before cutting to handling after cutting. The characteristics of a muscle have a close relationship with its function, because of its function, the amount of connective tissue differs between muscles. This connective tissue is related to the elasticity of the flesh. Furthermore, Lawrie (2003), suggests that differences in meat protein content can be caused by differences in muscle structure and activity levels. The difference in muscle types indicates a difference in nitrogen distribution so that different levels of muscle activity can produce different levels of meat protein. Physical properties play an important role in the processing process because physical properties determine the quality and type of preparation to be made. Physical properties are greatly influenced by factors before cutting and after cutting. An important factor before slaughtering is the rest treatment which can determine the level of stress (stress) in livestock. According to Aberle et al. (2001), livestock that is not rested will produce meat that is dark, hard-textured, dry, has a high pH value, and high water-binding capacity. An important factor after slaughter that affects the quality of the meat is withering. Withering meat will affect tenderness, flavor, and water-binding capacity. These factors are closely related to postmortem time or time after cutting.

Suarta, . G. ., Sukada, K. ., \& Suberata, W. . (2020). Comparison effecting of mixture on three meat factors and three culinary sectors on consumers in restaurant Nusa Dua. International Research Journal of Management, IT and

Social Sciences, 7(6), 146-152. https://doi.org/10.21744/irjmis.v7n6.1030 
The glycolysis process after slaughtering affects the $\mathrm{pH}$ value. The longer the postmortem time, the lower the $\mathrm{pH}$ will be due to the conversion process of muscle to meat at certain postmortem intervals. The ultimate $\mathrm{pH}$ value of normal meat ranges from 5.4-5.8 at 6 hours postmortem and the color of the meat will be bright red (Aberle et al., 2001). According to Lawrie (2003), the $\mathrm{pH}$ of meat can decrease rapidly to reach 5.4-5.5 hours after cutting. The $\mathrm{pH}$ standard for freshly slaughtered, healthy, well-rested animal flesh is 7-7.2 and will continue to decline for 24 hours. The drop in $\mathrm{pH}$ is not the same for all the tendons of an animal and it is different between animals. Postmortem $\mathrm{pH}$ value will be determined by the amount of lactic acid produced from glycogen during the anaerobic glycolysis process. The $\mathrm{pH}$ value will be lower in animals that are stressed before slaughtering and the meat will be pale, mushy, and juicy (pale, soft, exudative $=$ PSE).

Adiono (1985), added that the formation of lactic acid causes a decrease in the $\mathrm{pH}$ of the meat and causes damage to muscle protein structure and this damage depends on temperature and low $\mathrm{pH}$. After the animal is slaughtered, muscle oxygen supply stops, thus oxygen supply is no longer in the muscles and metabolic waste can no longer be removed from the muscles, so the meat will experience a decrease in $\mathrm{pH}$. Several characteristics of meat quality that are important in testing and influence consumer attractiveness are $\mathrm{pH}$, water holding capacity, color, and tenderness (Sutrisno et al., 2006). Water holding capacity is the ability of meat to retain water content subjected to external treatments such as cutting, heating, milling, and processing. The size of the water holding capacity affects the color, tenderness, elasticity, and texture of the meat (Suardana \& Swacita, 2009).

The binding capacity of meat water is strongly influenced by $\mathrm{pH}$, species, age, and muscle function as well as feed, transportation, temperature humidity, storage, sex, health, treatment before slaughter, and intramuscular fat (Soeparno, 2005). The $\mathrm{pH}$ value is one of the criteria in determining the quality of beef. The $\mathrm{pH}$ value of meat in live cattle is around 7.0-7.2 (neutral $\mathrm{pH}$ ). A decrease in the $\mathrm{pH}$ value will occur after the cattle are slaughtered (post-mortem), namely when the heart stops pumping blood so that the muscle tissue and other tissues do not get blood supply. Factors that affect the $\mathrm{pH}$ of meat include stress before slaughter, hormones/drugs, species, individual livestock and types of muscles, electrical stimulation, enzyme activity, and the occurrence of glycolysis, softening of collagen while cooking temperature affects myofibrillary strength more (Dwiloka et al., 2006). The number of cooking losses can be influenced by the amount of damage to the cellular membrane, the amount of water that comes out of the meat, the shelf life of the meat, protein degradation, and the ability of the meat to bind water (Shanks et al., 2002). Cooking shrinkage is an indicator of the nutritional value of meat-related to the moisture content of the meat, namely the amount of water that is bound in and between the muscles. Low water-holding capacity will result in high cooking losses. Water Holding Capacity (WHC) is strongly influenced by the $\mathrm{pH}$ value of the meat, according to Kadafi et al. (2005), if the $\mathrm{pH}$ value is higher or lower than the isoelectric point of meat (5.0-5.1), the cooking loss value of the meat will below. Bali and Wagyu beef have different organoleptic test values because there are different breeds of cattle that give different results of preference levels. Differences in these breeds may affect the physical characteristics of meat such as the value of water-binding capacity (DIA), acidity level ( $\mathrm{pH}$ ), and meat cooking loss. Cooking loss is a function of temperature and cooking time (Hartono et al., 2013).

\subsection{Physical Characteristics of Meat used in Culinary Mixtures}

\section{Cooking Loss}

Cooking loss is defined as the liquid lost or weight loss after the cooking process. Cooking loss is an indicator of the nutritional value of meat-related to the level of meat juice, namely the amount of water bound in nature and between muscle fibers (Soeparno, 2009). Lawrie (2003), states that good quality meat has less cooking losses than low-quality meat. Bouton et al. (1971) in Agus et al. (2009), stated that cooking losses can be influenced by pH, length of muscle fiber sarcomere, length of muscle fiber strips, myofibril contraction status, size of meat sample weight, and meat crosssection. As the cooking temperature increases and/or the cooking time takes longer, the greater the loss of liquid meat content until it reaches a constant level (Soeparno, 2009). Cooking losses will decrease linearly with the increasing age of the livestock. Differences in livestock breeds, slaughter weight, and feed consumption can also cause differences in cooking losses. This difference occurs due to differences in the amount of meat fat and fat deposition. The value of cooking loss varies between 1.5\% - 54.5\% with a range of 15\% -35\% (Romans \& Ziegler, 1974 in Syam, 2009).

\section{Color Score}

Color can also be used as an indicator of freshness or ripeness. Whether or not the mixing method or processing method 
can be marked by the presence of 11 uniform and even colors (Winarno, 2004). The color of cooked meat is generally gray. The color change is caused by the denaturation of globin and Maillard reactions. According to Lawrie (2003), in addition to being caused by pigments, the color change in cooked meat is also the result of the denaturation of globins and is influenced by carbohydrate caramelization and the Maillard reaction between reducing sugars and amino acids. Myoglobin is the main pigment of meat and its concentration will affect the intensity of the red meat. The difference in myoglobin levels causes differences in the intensity of meat color. The determinants of meat color are influenced by feed, species, breed, age, sex, stress (activity level, and muscle type).

\subsection{Organoleptic Properties}

Meat has organoleptic properties that can be related to the five basic properties, namely taste (smell), smell (smell), appearance/color (sight), subtlety (feel), and hardness. The four basic flavors identified from meat are salty, sour, sweet, and bitter (Abustam \& Ali, 2004). Organoleptic testing is testing based on the sensing process. Sensitivity is defined as a physio-psychological process, that is, the awareness or recognition of the sensory apparatus of the properties of an object due to the stimulus received by the sensory apparatus derived from the object. Sensitivity can also mean a mental reaction (sensation) if the sensory apparatus receives a stimulus (stimulus). An organoleptic test is a test of the properties of a food substance performed using the senses of taste, smell, sight, and touch. The test performed is a favorite test (hedonic test) which includes taste, aroma, color, texture, and softness.

The aroma is one of the organoleptic assessment parameters of a product. One thing that can affect the aroma of cooked meat is the cooking temperature. In general, the smell received by the nose and brain is more of a variety of ingredients or a mixture of four main ingredients, namely fragrant, sour, rancid, and charred (Winarno, 2004). Taste ranks first in consumer acceptance, the taste of a food ingredient is influenced by several factors, namely chemical compounds, temperature, consistency, and interactions with other taste components as well as the type and duration of cooking. The texture is the sensing associated with touch or touch. Characteristics that are often used as references are hardness, cohesiveness, and water content. The beef texture is largely determined by water content, fat content, and type of carbohydrates. Softness, according to Agus et al. (2009), that tenderness can be determined subjectively and objectively. The overall impression of tenderness includes three aspects. First, the initial ease of penetration of the teeth into the meat, secondly, the ease with which the meat is chewed into smaller pieces, and third, the amount of residue that remains after chewing conducted in the preference test (hedonic test) which includes taste, aroma, color, texture, and tenderness.

\subsection{Organoleptic quality}

The organoleptic quality of Bali beef is assessed as a predetermined panalis. In this study, the organoleptic parameters to be observed were color, texture, and taste, and the preference test which was conducted by 9 panelists. Previously, panelists were trained in the organoleptic properties to be tested. Assessment using the organoleptic quality scale test is assessed with a test scale of numbers 1 to 5. Panelists who already understand the criteria for the organoleptic scale to be tested are each given an assessment label. Panalis assesses by putting a cross on the label of the value chosen which is considered suitable according to them. Bali beef samples that were ready to be assessed were presented in each container according to the treatment planned in the study.

\section{Materials and Methods}

The research material used 3 types of culinary, namely: Kebab, Spaghetti, and Hamburger using a mixture of chicken, pork, and beef, which were obtained from several local restaurants and supermarkets in the Nusa Dua area of South Kuta Badung. Repetition of 3 x, to get 27 experimental units. The research started from January 5 to April 5, 2020, which is located at the Laboratory of Teknolagi and Animal Products, Faculty of Animal Husbandry, Udayana University. The measured variable is a quantitative variable that is the ratio or parametric, namely by measuring the number of consumers who buy each type of culinary mixture as follows:

1) KA: A mixture of Kebab and Chicken meat

2) KB: Kebab mix and pork

3) KS: A mixture of kebabs and beef

Suarta, . G. ., Sukada, K. ., \& Suberata, W. . (2020). Comparison effecting of mixture on three meat factors and three culinary sectors on consumers in restaurant Nusa Dua. International Research Journal of Management, IT and Social Sciences, 7(6), 146-152. https://doi.org/10.21744/irjmis.v7n6.1030 
4) SA: Mixture of Spagety and Chicken meat

5) SB: Spagety mix and Pork meat

6) SS: Spagety mix and Beef

7) HA: Hamberger mixture with chicken meat

8) HB: Mix Hamberger with pork

9) HS: Mixed Hamberger with Beef

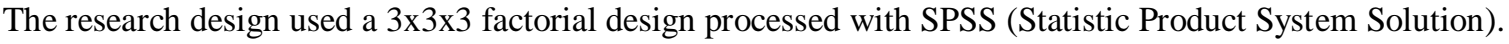

\section{Culinary}

Kebab is a culinary dish that has a wrapper of certain flour that is made in such a way that it is filled with meat which is cut into pieces according to treatment and filled with spices. Spaghetti is a culinary dish made from spaghetti noodles mixed with spices which also contain meat according to the treatment, this culinary appearance is very simple in the form of noodles filled with spices and finely minced meat (Macedo-Silva et al., 2000; Pariza et al., 1979). Hamburger is a food made from a burger bun that is split in the middle and then filled with thinly chopped meat pieces according to treatment. The first step is to make a variable treatment mix of each culinary with each meat according to the treatment planned in the experimental design, including:

1) Construction of a culinary train made from a mixture of kebab and chicken meat

2) Making culinary KB made from a mixture of kebab and pork

3) Making a culinary KS made from a mixture of kebab and beef

4) Making SA culinary made from a mixture of Spaghetti and Chicken meat

5) Making culinary SB made from a mixture of Spaghetti and Pork meat

6) Making culinary SS made from a mixture of Spaghetti and Beef

7) Making culinary HA made from a mixture of Hamberger and Chicken meat

8) Making culinary HB made from a mixture of Hamberger and pork

9) Manufacturing HS culinary made from a mixture of Hamberger and Beef

After all types of culinary mixed meats have been prepared, the number of customers who visit each type of culinary is recorded every day for a week and the average number of consumers is searched per day. The analysis used in this research is the variant analysis which is processed using the SPSS data processing method.

\section{Results and Discussions}

Table 1

Research data

\begin{tabular}{llll}
\hline & \multicolumn{3}{c}{ Chicken meat } \\
\hline \multirow{4}{*}{ Kebab } & 80 & 40 & 47 \\
& 17 & 18 & 28 \\
& 24 & 14 & 17 \\
Spaghetti & 30 & Pork & \\
& 21 & 18 & 29 \\
& 18 & 23 & 19 \\
& & Beef & 15 \\
Hamberger & 40 & 20 & 17 \\
& 43 & 25 & 20 \\
& 39 & 19 & 21 \\
\hline
\end{tabular}




\begin{tabular}{lllllll}
\hline Source & Type III, SS & Df & MS & F & Sig. & \\
\hline Corrected & 3993,704 & 10 & 399,370 & 5,273 & 0,002 & $*$ \\
Intercept & 20117,370 & 1 & 20117,370 & 265,592 & 0,000 & $* * *$ \\
Meat & 329,892 & 2 & 164,962 & 2,177 & 0,146 & Ns \\
Culinary & 144,963 & 2 & 720,481 & 9,512 & 0.002 & $*$ \\
* Culinary & 1489,481 & 4 & 372,370 & 4,961 & 0,09 & Ns \\
Meat & & & & & & \\
Error & 1211,926 & 16 & 75,745 & & & \\
Total & 25323,000 & 27 & & & & \\
Total corrected & 5205,630 & 26 & & & & \\
\hline
\end{tabular}

\section{Discussion}

The type of meat factor has no effect on the number of consumer visits, according to the results of the Duncan test, it is found that the number of consumers who buy culinary mixed with chicken meat is 31.67 percent $(\mathrm{P}>0.05$, the number of consumers who buy culinary with a mixture of beef is $21.11 \%(\mathrm{P}>0.05)$, while the number of consumers who bought culinary delights with a mixture of pork was 23.11 portions $(\mathrm{P}>0.05)$. Culinary type factors, among others: kebabs, spaghetti, and hamburger affect the amount of culinary purchased by consumers such as The number of consumers who buy kebabs is 37.56 porcelain $(\mathrm{P}<0.05)$, while the number of consumers who buy spaghetti is 23,22 porcelain $(\mathrm{P}<0.05)$ and the number of consumers who bought the hamburger culinary type was 21.11 portions $(\mathrm{P}$ $<0.05)$.

\section{Conclusion}

Based on the results of the study, it was found that the most preferred taste based on the panelists and data processing obtained the highest taste, color, and smell respective: kebab, hamburger, and spaghetti.

\section{Conflict of interest statement}

The authors declared that they have no competing interests.

\section{Statement of authorship}

The authors have a responsibility for the conception and design of the study. The authors have approved the final article.

\section{Acknowledgments}

On this occasion, the author would like to thank Mr. Dr. Ir. I Nyoman Tirta Ariana, MS, as Dean of the Faculty of Animal Husbandry, Udayana University, has provided research facilities and sites to the author.

Suarta, . G. ., Sukada, K. ., \& Suberata, W. . (2020). Comparison effecting of mixture on three meat factors and three culinary sectors on consumers in restaurant Nusa Dua. International Research Journal of Management, IT and Social Sciences, 7(6), 146-152. https://doi.org/10.21744/irjmis.v7n6.1030 


\section{References}

Aberle, H. B., Forrest, J. C., Gerrard, D. E., \& Mills, E. W. (2001). Principle of Meat Science, 4 th Edit. Kendall/Hunt Publ. Co., Iowa.

Abustam, E., \& Ali, H. M. (2004). Bahan Ajar Ilmu dan Teknologi Pengolahan Daging. Fakultas Peternakan. Universitas Hasanuddin, Makassar.

Adiono, P. H. (1985). Ilmu Pangan. Jakarta: Universitas Indonesia.

Agus, F., \& Afina, T. Bekti dan Soeparno. 2009. Karakteristik Sosis Dengan Fortifikasi ß-Caroten Dari Labu Kuning, 111-118.

Bouton, P. E., HARRIS, P. T., \& Shorthose, W. R. (1971). Effect of ultimate pH upon the water-holding capacity and tenderness of mutton. Journal of food science, 36(3), 435-439.

Dwiloka, B., Rianto, E., \& Ekawati, R. (2006). Perbandingan Kualitas "Blade" Sapi Lokal dan Sapi Impor yang Diolah dengan Metode "Pan Frying”. Jurnal Sains dan Teknolog I Hasil Ternak, 2(1), 8-22.

Gallegos-Infante, J. A., Rocha-Guzman, N. E., Gonzalez-Laredo, R. F., Ochoa-Martínez, L. A., Corzo, N., BelloPerez, L. A., ... \& Peralta-Alvarez, L. E. (2010). Quality of spaghetti pasta containing Mexican common bean flour (Phaseolus vulgaris L.). Food Chemistry, 119(4), 1544-1549. https://doi.org/10.1016/j.foodchem.2009.09.040

Hartono, E., Iriyanti, N., \& Santosa, R. S. S. (2013). Penggunaan pakan fungsional terhadap daya ikat air, susut masak, dan keempukan daging ayam broiler. Jurnal Ilmiah Peternakan, 1(1), 10-19.

Kadafi, M., \& Widaningroem, R. Soeparno. 2005. Biological Aspects and Maximum Sustainable Yield of Spiny Lobster (Panulirus spp) in Ayah Coastal Waters Kebumen Regency, 108-117.

Larsson, A., \& Sjöquist, J. (1990). Chicken IgY: utilizing the evolutionary difference. Comparative immunology, microbiology and infectious diseases, 13(4), 199-201. https://doi.org/10.1016/0147-9571(90)90088-B

Lawrie, RA (2003). Ilmu Daging. Edisi Kelima. UI-Press, Jakarta.

Macedo-Silva, A., Barbosa, S. F. C., Alkmin, M. G. A., Vaz, A. J., Shimokomaki, M., \& Tenuta-Filho, A. (2000). Hamburger meat identification by dot-ELISA. Meat Science, 56(2), 189-192. https://doi.org/10.1016/S03091740(00)00039-5

Pariza, M. W., Ashoor, S. H., Chu, F. S., \& Lund, D. B. (1979). Effects of temperature and time on mutagen formation in pan-fried hamburger. Cancer Letters, 7(2-3), 63-69. https://doi.org/10.1016/S0304-3835(79)80097-X

Romans, J. R., \& Ziegler, P. T. (1974). The Meat We Eat 10" edition. The interstate Printers and Publishers Inc., Danville, Illinois.

Shanks, B. C., Wulf, D. M., \& Maddock, R. J. (2002). The effect of freezing on Warner-Bratzler shear force values of beef longissimus steaks across several postmortem aging periods. Journal of Animal Science, 80(8), 2122-2125.

Short, F. J., Gorton, P., Wiseman, J., \& Boorman, K. N. (1996). Determination of titanium dioxide added as an inert marker in chicken digestibility studies. Animal feed science and technology, 59(4), 215-221. https://doi.org/10.1016/0377-8401(95)00916-7

Sozer, N., Dalg1c, A. C., \& Kaya, A. (2007). Thermal, textural and cooking properties of spaghetti enriched with resistant starch. Journal of Food Engineering, 81(2), 476-484. https://doi.org/10.1016/j.jfoodeng.2006.11.026

Suardana, I. W., \& Swacita, I. B. N. (2009). Higiene Makanan. Kajian Teori Dan Prinsip Dasar. Fakultas Kedokteran Hewan. Universitas Udayana, Denpasar.

Sutrisno, E. P. C., Budhi, E. B. S., \& Lestariana, W. (2006). Karakteristik fisik otot Longissimus dorsi dan Biceps femoris domba lokal jantan yang dipelihara di pedesaan pada bobot potong yang berbeda. Jurnal protein, 13(2).

Widyantara, I. N. P., \& Sukaatmadja, I. P. G. (2019). Formulation of chicken egg marketing strategy. International research journal of management, IT and social sciences, 6(5), 285-302.

Winarno, F. G. (2004). Ilmu pangan dan gizi. Jakarta: Gramedia Pustaka Utama. 